\title{
Correlation of EGFR (Her1) expression with clinical features in sinonasal squamous cell carcinoma
}

\author{
N.D. Phuc ${ }^{1}$, L.M. Ky ${ }^{1}$, N.T. Binh ${ }^{2}$, V.T.M. Thuc ${ }^{1}$, N.T. Tuan ${ }^{3}$, \\ N.T.K. $\operatorname{Van}^{1}$ and T.X. Hai ${ }^{4}$ \\ ${ }^{1}$ National ENT Hospital, Vietnam. \\ 2 Thaibinh Pharmacy-Medical University, Vietnam \\ ${ }^{3}$ Vinh Medical University-Nghe An-Vietnam \\ ${ }^{4}$ Nghe An Maternity - Pediatric Hospital, Viet Nam \\ Corresponding author: V.T.M. Thuc \\ E-mail: vuminhthuc2010@yahoo.com.vn
}

Genet. Mol. Res. 20 (1): gmr18749

Received December 30, 2019

Accepted April 20, 2020

Final Revision January 25, 2021

Published March 30, 2021

DOI http://dx.doi.org/10.4238/gmr18749

\begin{abstract}
Prognosis of sinonasal squamous cell carcinoma (SNSCC) depends on TNM (Tumor, Node, Metastasis) staging, histological manifestations, and activity of cell-surface receptors (p53, Ki67, EGFR - Epidermal Growth Factor Receptor (ErbB-1; Her1). EGFR is the best- studied transmembrane tyrosine kinase receptor. The intensity of tumor cells division and the rate of their metastasis depend on EGFR. It also regulates the processes of angiogenesis. All this determines the severity of the course of the disease and the ability to predict its outcome. Depending on the speed of EGFR expression, targeted therapy may or may not be prescribed. The clinical picture and prognosis of SNSCC depends on the rate of EGFR expression. We conducted a prospective case study on 32 SNSCC patients treated at the National Ear Nose and Throat Hospital during two years (2011-2012). Clinical presentations and computed tomography scan imaging were analyzed and biopsy samples were examined to investigate EGFR activity (Her1). A semi quantification technique was used. The level of EGFR expression was correlated with disease staging. The rate of positive EGFR expression in
\end{abstract}


SNSCC was $17 / 32 ; 8 / 32$ scored $3+$. EGFR was positive in $16 / 32$ stage III patients. The EGFR-positive rate was higher in exophytic, advanced stage cancer, with neurological deficits and lymphadenopathy of the neck. EGFR expression was increased in $17 / 32$ of sinonasal squamous cell carcinoma samples. Patients with more severe manifestations, including neurological symptoms, facial deformities and exophytic tumor growth had a significantly higher EGFR expression rate.

Key words: Sinonasal cancer; EGFR; Epidermal Growth Factor Receptor (ErbB-1; Her); Squamous cell carcinoma; SNSCC

\section{INTRODUCTION}

Sinonasal cancer is relatively uncommon, accounting for less than $1 \%$ of all neoplasms and about 3\% of those arising in the head and neck region (Đoàn et al., 2018). Until now, the literature search shows approximately 2000 articles with diverse analysis corresponding to sinonasal cancer. Prognosis depends on many factors (Piccirillo and Feinstein, 2016) such as clinical staging, histologic types (undifferentiated carcinoma is more aggressive than differentiated type, malignant lymphoma has worse prognosis than that of squamous tumors) and the degree of malignancy evaluated by measurements of biomarkers (p53, Ki67 and Epidermal Growth Factor Receptor (EGFR) (Her1)). A number of previous studies have shown that immunohistochemical overexpression of EGFR correlates with a poor prognosis of malignancy. At the same time, the expression of EGFR is considered an attractive target for anti- marker of cancer EGFR therapy in various types of oncology (Hashmi et al.,2018). In Vietnam, EGFR is being actively studied as a processes. It becomes an object of study not only for sinonasal cancer, but also for lung cancer (Phạm et al., 2018), lymphoma (Thi et al., 2018), maxillary sinus (Maemondo, 2010), and colorectal cancer. But meta-studies have not been conducted. Many findings are published exclusively in Vietnamese and were not submitted for publication in international journals.

The aims of this study were:

Determine the rate of EGFR expression in biopsy samples of epithelium of sinonasal sinuses .

Collate the rate of EGFR activity with clinical features in squamous cell carcinoma (SNSCC).

\section{MATERIAL AND METHODS}

Thirty-two SNSCC patients were treated at National ENT (Ear Nose Throat) Hospital in two years (2011-2012). All patients were informed about the study and gave their consent to participate in it. They also agreed to publish the data

The research was conductd in accordance with the standards of the committee on experiments with people in Vietnam and the Helsinki Declaration of 1975 (revision of 2000).

A prospective case study was conducted.

Data of clinical presentations and CT scan images were collected. 
Fixed biopsy samples in $10 \%$ neutral buffered formalin were transferred to Department of Pathology Hanoi Medical University for HE (hematoxylin and eosin) and PAS (Periodic acid-Schiff) stains (PAS stain for adenocarcinoma and follicular carcinoma to identify mucous substance).

Tumors were categorized according to the WHO (World Health Organization) histological classification 2005.

Immunostaining for EGFR (Her1) was performed in all SNSCC cases.

Her1-status was scored as follow: negative $=$ no staining of tumor cells, $(1+)=$ light brown staining $10-30 \%$ tumor cells, $(2+)=$ brown staining $>30 \%$ tumor cells, $(3+)=$ strong brown staining $>30 \%$ tumor cells. This classification helped evaluate the pace of EGFR expression in each group.

All data was analyzed using a common statistics algorithm.

All patients signed a voluntary informed consent to participate in the study. The study design, informed consent form was reviewed and approved by the bioethics experiment and the expert ethics committee of our institution.

\section{RESULTS}

\section{Histologic characteristics}

We found three histological types of tumors in the 32 cases (Table 1).

Among the 32 cases, 28 were SCC, three were adenocarcinoma, and one was undifferentiated squamous cell carcinoma.

Among the 32 cases, 24 had a highly differentiated tumor occupy, and eight cases had poorly differentiated tumors.

In South Asia, head and cervical cancers are the third leading cause of cancerrelated morbidity and mortality (Naz et al., 2015; Bhayekar et al., 2016; Gupta et al., 2017). Approximately 90 to $95 \%$ are oral squamous cell carcinoma (SCC). AC and USCC and are less common. The frequency of pathologies in this study was similar to these general estimates.

Table 1. Histologic characteristics of the 32 biopsy specimens.

\begin{tabular}{llllr}
\hline & SCC & AC & USCC & Total \\
\hline Highly differentiated & 22 & 2 & 0 & 24 \\
Poorly differentiated & 6 & 1 & 1 & 8 \\
Total & 28 & 3 & 1 & 32 \\
\hline SCC: squamous cell carcinoma, AC: adenocarcinoma, USCC:undifferentiated squamous cell carcinoma.
\end{tabular}

These kinds of cancer show varied degrees of epithelial dysplasia and malignancy. The rate of EGFR expression also varied.

\section{EGFR status}

EGFR expression was detected in 17 of 32 cases. Eight cases of these 17 were scored 3+ (Table 2). 
Table 2. Number of patients with identified Epidermal Growth Factor Receptor expression.

\begin{tabular}{ll} 
& \\
\hline Status & $\mathbf{n}$ \\
\hline Negative & 15 \\
$1+$ & 4 \\
$2+$ & 5 \\
$3+$ & 8 \\
Total & 32 \\
\hline
\end{tabular}

Expression of EGFR in a number of epithelial cell tumors in humans has been well documented, and $80 \%$ of squamous cell carcinomas are marked by overexpression of EGFR, resulting in proliferation and differentiation of keratinocytes. High expression of EGFR in head and neck SSC has been reported by some another studies (Xia et al., 1999; Ene et al., 2012). In a similar study conducted by Sarkis et al. (2010), the EGFR immunostaining was positive in $87.5 \%$ of the cases (Laimer et al., 2007). Moreover, $92.3 \%$ of cases were positive for EGFR staining in the study conducted by Hiraishi et.al (2006).

\section{Correlation of EGFR expression with clinical presentations}

Among 28 stage III patients, 14 cases were EGFR-positive, and six patients were scored. Among four stage IV patients, three were EGFR-positive, and two were scored 3+ (Table 3).

The EGFR expression level correlates with the degree of the oncological process according to the clinical classification. It opens up opportunities for early staging and quick response to critical situations.

Table 3. EGFR - positive patients.

\begin{tabular}{llll}
\hline & S III & SIVA & n \\
\hline Negative & 14 & 1 & 15 \\
$1+$ & 3 & 1 & 4 \\
$2+$ & 5 & 0 & 5 \\
$3+$ & 6 & 2 & 8 \\
Total & 28 & 4 & 32 \\
\hline
\end{tabular}

\section{EGFR expression associated with tumor morphology}

The rate of EGFR expression in exophytic and exophytic tumors with polyps was 13/24 and $4 / 8$, respectively (Table 4 ). This difference was not significant.

Table 4. EGFR expression with squamous cell carcinoma morphology.

\begin{tabular}{llll}
\hline & Positive & Negative & P \\
\hline Exophytic $(\mathrm{n}=24)$ & 13 & 11 & $>0.5$ \\
Exophytic with polyp $(\mathrm{n}=8)$ & 4 & 4 & 15 \\
Total & 17 & 15 & \\
\hline
\end{tabular}




\section{EGFR and facial deformities}

Table 5 demonstrates that the rate of EGFR expression in sinonasal cancer with facial deformities was higher than that of cases without facial deformities.

Table 5. EGFR associated with facial deformities.

\begin{tabular}{llll}
\hline & EGFR (+) & EGFR (-) & P \\
\hline With facial deformities & 6 & 1 & $<0.05$ \\
Without facial deformities & 11 & 14 & \\
Total & 17 & 15 & \\
\hline
\end{tabular}

\section{EGFR associated with eye damage}

The rate of EGRF-positive cases with and without eye damages were similar (Table 6).

Table 6. EGFR expression and eye damages.

\begin{tabular}{llll}
\hline & EGFR $(+)$ & EGFR (-) & P \\
\hline With eye damage & 4 & 4 & $>0.5$ \\
Without eye damage & 13 & 11 & \\
Total & 17 & 15 & \\
\hline
\end{tabular}

\section{EGFR associated with neurological deficits}

The rate of EGRF-positive cases with and without neurologic deficits did not differ significantly (Table 7).

Table 7. EGFR and neurologic deficits (ND).

\begin{tabular}{llll}
\hline & EGFR (+) & EGFR (-) & P \\
\hline With ND & 12 & 9 & $>0.05$ \\
Without ND & 5 & 6 & \\
Total & 17 & 15 & \\
\hline
\end{tabular}

\section{EGFR and cervical lymphadenopathy}

The rate of EGFR expression in cases with cervical lymphadenopathy was significantly higher than that of cases without cervical lymphadenopathy (Table 8). 


\begin{tabular}{|c|c|c|c|}
\hline & EGFR $(+)$ & EGFR (-) & $P$ \\
\hline With CL & 4 & 0 & \multirow{3}{*}{$<0.05$} \\
\hline Without CL & 13 & 15 & \\
\hline Total & 17 & 15 & \\
\hline
\end{tabular}

\section{DISCUSSION}

\section{The rate of EGFR expression}

In our 17 of 32 patients were EGFR-positive. Those that scored 3+ accounted for $8 / 32$. Thus, our prediction of success with radiotherapy and targeted therapy, represented by EGFR-plus expression, was 17/32. In oncogenesis, it is well known that atypical cells are transformed from normal cells. These cells bring the altered genome that disrupts the programming regulating the balance between cell division and programmed cell death. These cancer cells need to be activated through various oncogenic signaling pathways to grow; otherwise no cell division occurs and therefore the tumor will not develop. One of the well-known pathways is through the epidermal growth factor (EGF) signaling pathway (Zafar et al., 2017).

This pathway is a family consisting of four closely related transmembrane TK (tyrosine kinase) receptors Her1, Her2, Her3 and Her4. Her1 (also known as EGFR) is one of the identified receptors that exists on the surface of malignant cells in the head and neck squamous cell carcinoma, adenocarcinoma of the lung and some types of colorectal cancer. Kalyankrishna and Grandis (2006) reported that the EGFR overexpression in squamous cell carcinomas, including those in the head and neck region, may reach up to $90 \%$. EGFR plays an important role in promoting tumor growth, invasion, metastasis and angiogenesis. So far, some drugs targeting at EGFR inhibition have been applied and showed promising clinical benefits. Optimization of the EGFR inhibition therapy can be achieved by identification and selection of the SCCs, which potentially have the greatest response to targeted therapy (Greene et al., 2006; Thi et al., 2018). To precisely identify the EGFR mutation, which aims targeting treatment with Figitumumab or Celecoxib, the quantification techniques such as fluorescence or silver in situ hybridization) must be used (Sok et al., 2006; Sundvall et al., 2010; Bernardes et al., 2013). Due to limitation of resources and techniques, only the semi quantification technique had been used to determine the rate of EGFR expression and collate with disease staging. Molecular diagnosis is expensive, so this test is used only in EGFR-positive cases detected by immunohistochemistry for the validation of targeted therapy.

\section{Histologic types and EGFR}

Our results showed that the majority of sinonasal cancers were SCCs $(28 / 32)$. The rest were adenocarcinoma (3/32) and undifferentiated cancer (1/32). Our results were similar to those of other authors (Lê Văn Bích and Phạm Khánh Hoà, 1969; Nguyễn Mạnh Cường, 1978; Nguyễn Công Thành, 1991; Vũ Công Trực, 1996; Trần Thị Hợp, 1996; Phùng Quang Tuấn, 2009; Lê Trung Thọ et al., 2011; Phạm Mai Thủy Tiên et al., 2018). We also noted 
that squamous pearls were not present in SNSCCs samples, in contrast to SCCs at other sites that have the same embryologic origin (in bronchial cancer) (Maemondo, 2010). This feature predicts a better outcome with radiotherapy of SNSCC than that at other sites.

The rate of highly and poorly differentiated SCC in our study were $22 / 32$ and $6 / 32$, respectively. Although squamous pearls were absent, intercellular bridges found in loose tumor cell clusters were the diagnostic morphological features of SCC. Among three adenocarcinoma cases, two had highly differentiated tumors. Thus, we assumed that most of the sinonasal cancers were highly differentiated tumors with slow progression and rare metastasis despite their large size.

\section{EGFR and clinical presentations.}

Among 28 stage III patients, half (14/28) were EGFR positive, among which six cases scored $3+$. Among four stage IV patients, three were EGFR positive and half $(2 / 4)$ scored 3+. Our preliminary results showed that stage III patients were more EGFR negative than stage IV and had a higher level of EGFR overexpression in stage IV than stage III. Thus, the rate and level of EGFR overexpression increased with advanced stages of disease. This was also found by other studies (Sozzi et al., 2018) andSok et al. (2006). Tumor cells with EGFR expression grew more rapidly than those without that marker (Greene et al., 2006).

In correlating with clinical presentations, our results showed the number of EGFRpositive expression was higher in exophytic than in exophytic with polyp forms, in advanced stage with facial deformities than localized stage and in stage with neurologic deficits. We also noted that all four patients with cervical lymphadenopathy were EGFRpositive. But we were unable to compare our results with others due to the lack of data for Vietnam.

There are a lot of other areas for research concerning this topic. For example, certain reverse TK pathways are activated by the inhibition of te EGFR. These pathways can escape the influence of EGFR; thus we need to consider alternative molecular targets for multimodal therapy. The capacity of cancer cells to adapt to different classes of drugs suggests that additional mechanisms of resistance to EGFR inhibitors may play a key role in regulating tumor response, such as the induction of angiogenesis process, translocation of surface receptors to the nucleus, altered DNA damage response, and all other undiscovered mutations.

\section{CONCLUSIONS}

The rate of EGFR expression in SNSCC was 17/32, and 8/32 scored 3+. The rate of EGFR expression was 14/28 in stage III patients (6/14, scored $3+$ ). EGFR expression was higher in exophytic form, advanced stage with facial deformities, significantly higher in cases with neurological deficits and cervical lymphadenopathy.

We found a significant association of EGFR expression with tumor stage and clinical features, which are the most important prognostic factors in head and neck squamous cell carcinoma, including sinonasal cancer. Therefore, EGFR expression can help as a prognostic biomarker in head and neck squamous cell carcinoma. 


\title{
ACKNOWLEDGMENTS
}

The authors are grateful to National ENT Hospital (National Ear Nose Throat Hospital) for the financial support.

\section{CONFLICTS OF INTEREST}

\author{
The authors declare no conflict of interest.
}

\section{REFERENCES}

Bernardes VF, Gleber-Netto FO, de Sousa SF, Rocha RM, et al. (2013). EGFR status in oral squamous cell carcinoma: comparing immunohistochemistry, FISH and CISH detection in a case series study. BMJ Open. 3(1): e002077. DOI:10.1136/bmjopen-2012-002077.

Bhayekar PD, Gaopande VL, Joshi AR and Jadhav AB (2016). Immunohistochemical study of p53, Ki-67, epidermal growth factor receptor, and sex-determining region Y-box 2 in squamous cell carcinoma of tongue. BLDE Univ. J. Health Sci. 1(2): 102-107. DOI: 10.4103/2468-838X.196089.

Ene P, Popescu R, Voiculescu S, Scaunasu R, et al. (2012). The Role of EGFR and HER2-Activating Mutations in Maxillary Sinus Cancer. Maedica, 7(1):70-74.

Greene FL, Compton CC, Fritz AG, Shah JP, et al. (2006). AJCC Cancer Staging Atlas (Vol. 293). NY: Springer.

Gupta N, Gupta R, Acharya AK, Patthi B, et al. (2017). Changing trends in oral cancer - a global scenario. Nepal J. Epidemiol. 6(4): 613-619. DOI: 10.3126/nje.v6i4.17255.

Hashmi A, Hussain ZF, Aijaz S, Irfan M, et al. (2018). Immunohistochemical expression of epidermal growth factor receptor (EGFR) in South Asian head and neck squamous cell carcinoma: association with various risk factors and clinico-pathologic and prognostic parameters. World J Surg Onc. 16: 118. https://doi.org/10.1186/s12957-0181425-3.

Hiraishi Y, Wada T, Nakatani K, Negoro K, et al. (2006). Immunohistochemical expression of EGFR and p-EGFR in oral squamous cell carcinomas. Pathol. Oncol. Res. 12(2): 87-91. DOI: 10.1007/BF0289345.

Kalyankrishna S and Grandis JR (2006). Epidermal growth factor receptor biology in head and neck cancer. J. Clin. Oncol. 24(17): 2666-2672. DOI: 10.1200/JCO.2005.04.830.

Laimer K, Spizzo G, Gastl G, Obrist P, et al. (2007). High EGFR expression predicts poor prognosis in patients with squamous cell carcinoma of the oral cavity and oropharynx: a TMA-based immunohistochemical analysis. Oral Oncol. 43: 193-198. DOI: 10.1016/j.oraloncology.2006.02.009.

Lê TT, Bùi TMH and Nguyễn CH (2011). Đặc điểm ung thư sàng hàm. Y Học Thành Phố Hồ Chí Minh. 2(15): 29-35.

Lê VB and Phạm KH (1969). Nghiên cứu trên 60 u ác tính sàng hàm gặp tại khoa TMH bệnh viện Bạch mai từ 1960 1968. Nội San TMH. 12: 73-79.

Maemondo M (2010). Gefitinib or Chemotherapy for Non-Small-Cell Lung Cancer with Mutated EGFR. N. Engl. J. Med. 362: 2380-2388. DOI: 10.1056/NEJMoa0909530.

Naz S, Salah K, Khurshid A, Hashmi AA, et al. (2015) Head and neck squamous cell carcinoma - comparative evaluation of pathological parameters in young and old patients. Asian Pac. J. Cancer Prev. 16(9): 4061-4063. DOI: 10.7314/APJCP.2015.16.9.4061.

Nguyễn CT (1991). Một số nhận xét về ung thu sàng hàm tại Viện Tai Mũi Họng tù̀ 1986 - 1990. Luận Văn Tốt Nghiệp Bác Sỹ Nội Trú Bệnh Viện.

Nguyễn MC (1978). Những biểu hiện lâm sàng, tổ chức bệnh học, điện quang của 52 trường hợp ung thư biểu mô khối sàng hàm. Luận Văn Tôt Nghiệp Chuyên Khoa, II.

Phạm MTT, Phạm NH, Phan CD, Nguyễn TÁ, et al. (2018). My Đánh giá kết quả điều trị bước một ung thư phổi không tế bào nhỏ giai đoạn tiến xa, di căn có đột biến Egfr bằng thuốc ức chế Tyrosine kinase (TK1s). Tạp Chi Y Học Lâm Sàng. 50: 60-67.

Phùng QT (2009). Nghiên cưu đặc điểm lâm sàng, chẩn đoán hình ảnh và mô bệnh học của ung thu sàng hàm. Luận văn Thạc sĩ. Hà Nội: Đại Học Y.

Piccirillo JF and Feinstein AR (2016). Clinical symptoms and comorbidity: significance for the prognostic classification of cancer. Cancer. 77(5): 834-842. DOI: 10.1002 / (SICI) 1097-0142 (19960301) 77: 5 <AID-CNCR5> 3,0.CO; 2 E.

Sarkis SA, Abdullah BH, Majeed BAA and Talabani NG (2010). Immunohistochemical expression of epidermal growth factor receptor (EGFR) in oral squamous cell carcinoma in relation to proliferation, apoptosis, angiogenesis and lymphangiogenesis. Head Neck Oncol. 2(1): 13. DOI: 10.1186/1758-3284-2-13. 
Sok JC, Coppelli FM, Thomas SM, Lango MN, et al. (2006). Mutant epidermal growth factor receptor (EGFRvIII) contributes to head and neck cancer growth and resistance to EGFR targeting. Clin. Cancer Res. 12(17): 50645073. DOI: 10.1158/1078-0432.CCR-06-0913.

Sozzi G, Miozzo M, Tagliabue E, Calderone C, et al. (2018) Cytogenetic abnormalities and overexpression of receptors for growth factors in normal bronchial epithelium and tumor samples of lung cancer patients. Cancer Res. 51(1): 400404.

Sundvall M, Karrila A, Nordberg J, Grénman R, et al. (2010). EGFR targeting drugs in the treatment of head and neck squamous cell carcinoma. Expert Opin. Emerg. Drugs. 15(2): 185-201. DOI: 10.1517/14728211003716442.

Trần TH (1996). Góp phần chẩn đoán và điều trị ung thư sàng hàm. Nhận xét qua 174 ca ung thư sàng hàm tại viẹn TMH và Viện K Hà Nội. Luận Án Chuyên Khoa, II (Chuyên Ngành Ung Thư).

Thi $\mathrm{D}$, Văn $\mathrm{BN}$, Hưng $\mathrm{T}$, et al. (2018). Nghiên cứu đặc điểm mô bệnh học và hóa mô nhiễm dịch u lympho không hodgkin tại Bệnh viện Trung ương Huế (2014 - 2017). Tạp Chí Y Học Lâm Sàng. 50: 96-102.

Vũ CT (1996). Góp phần tìm hiểu dịch tễ học, chẩn doán ung thu sàng hàm và một số tác nhân sinh bệnh liên quan. Luận Văn Tốt Nghiệp Thạc Sỹ Y Học.

Xia W, Lau YK, Zhang HZ, Xiao FY, et al. (1999). Combination of EGFR, HER-2/neu, and HER-3 is a stronger predictor for the outcome of oral squamous cell carcinoma than any individual family members. Clin. Cancer Res. 5(12): 4164-4174.

Zafar M, Hashmi SN, Faisal MJ, Ahmed R, et al. (2017). Immunohistochemical expression of epidermal growth factor receptor in head and neck squamous cell carcinoma. J. Coll. Physicians Surg. Pak. 27(4): 209-212. 